\title{
ANALYSIS OF THE RIGID PAVEMENT ROAD DAMAGES IN THE SEGMENTS OF PEMALANG - TEGAL: A RESEARCH REVIEWED FROM THE ISSUES OF IMPLEMENTATION AND HANDLING
}

\author{
Sabilirrahman ${ }^{1}$ \\ Rachmat Mudiyono ${ }^{2}$ \\ Civil Engineering, Sultan Agung Islamic University Semarang ${ }^{1,2}$ \\ Corresponding Author Email: rachmat@unissula.ac.id
}

\begin{abstract}
Road as a transportation system has an important role in Indonesia compared to other modes of transportation such as air and sea transportation. As road is found to be important, this condition must be maintained to keep it in a good condition. In fact, road damage still occurs that it can bother the road users and disrupt the pace of the economic activities of the community. Therefore, a research is needed to get to know factors that cause damages to the road segments of Pemalang - Tegal. This research belongs to descriptive research conducted by previously testing the validity and reliability of the research approach. It is done by looking for factors that cause damages to rigid pavement roads in terms of implementation, and factors causing the type of dominant damage and how to handle it. This resarch was conducted to 70 respondents using a questionnaires previously tested for validity and reliability. Data were obtained from the questionnaires filled by the respondents and then statistically processed through SPSS and AHP method. The results show that one of the causes of rigid pavement road damage viewed from implementation was the poor material processing system. The most dominant types of damages were abrasion, release of granules and wear. by overlaying in a damaged location.
\end{abstract}

Keywords: Causes, Types of damage, How to handle the road 


\section{Introduction}

In accordance with the new government vision, one of which is building regional infrastructure, primarily in the frame of building road as a facility to connect areas between province and regency. In addition to building some other new facilities, regular maintenance to the existing infrastructures previously built years before is needed. Maintenance on the road infrastructure can be executed by priority and so the construction made is expected to be under-control based on the planning. Land transportation has a significant role and it is in fact dominant in Indonesia compared to other transportation modes such as air and sea transports. Either regular road improvement or maintenance is needed and what makes it support and increase the economic activities in Indonesia, mainly to the area of Pemalang - Tegal. Industrial sectors such as fisheries, garment, tea, and sugar cane plantation as well as special culinary such as "Warteg" around the main road of Pemalang - Tegal are kinds of sectors vital in the line of Pemalang - Tegal where it corresponds to the positive growing of these sectors. Therefore, a good road infrastructure that supports development of the sectors in Pemalang Tegal is required, and one of which can possibly be made by maintaining the road connecting the area of Pemalang - Tegal in Pantura. Road segments of Pemalang - Tegal are primary transportation roads to connect the area of Central Java and West Java through the north coastline of Java Island. This area is recorded to experience from development. This road of Pemalang - Tegal is located in the north coastline connecting Central Java and Brebes regency to which it is bordering with West Java with the distance of $36.300 \mathrm{Km}$. This time, the road segments are found to be very busy, hollow in the rainy season and experiencing cracks due to varieties of factors such as traffic density and overloaded vehicles passing by these roads. Therefore, it needs an effective regular maintenance. This research is aimed at analyzing factors causing damage in the busy line of Pemalang - Tegal viewed from the aspect of implementation and dominating factors causing the damage. In addition, it is also an effort to find out ways to deal with the issues happening in the road segments of Pemalang - Tegal.

\section{Literatur Riview}

\subsection{Transportation}

Transportation is a way to carry humans or goods from one place to another place by making use of modes operated by humans or machines. One of the transportation modes that 
nowadays becomes the mainstay of economy is land transport. Road infrastructure construction has been truly proven to ease the transport of human, goods and service as well as information to all over the regions. In order to safely and comfortably serve the community, sufficient road accesses are necessitated. Road damages are problems commonly turn up and get attention what make them require special treatment in term of correctly doing the maintenance to minimize damage and lengthen the age of plan. Warpani (1990) argues that transport is needed due to source of human need is not available everywhere. Source in the form of raw materials has to go through production stage to which its location is not always in the site where humans as consumers live. This discrepancy of distance between the source of location, production and consumers is an issue trigges the transportation. There are five main elements in transportation:

a. Human

b. Goods

c. Vehicles as a means of transportation

d. Road as the infrastructure of transportation

e. Organization, transport organizer

Those five elements have each feature needed for consideration in term of understanding issues relevant to transportation. Basically, in carrying out and performing the transport, there should be guarantee that passengers and/ or goods transported will safely arrive in the destination in a good condition as it is before being transported. This guarantee cannot be fulfilled without first knowing the characteristics of passengers and goods as well as the conditions and construction of facilities, infrastructure and implementation of transportation

\subsection{Road Definition}

Roads are land transportation infrastructures that cover all parts of the road, including complementary buildings and facilities which are intended for traffic, located at ground level, above ground level, below the surface of the land and/ or water, and above the water surface, except railway, and lines of lorry and cable (Law No. 38, year 2004 concerning roads). Public roads are ways intended for public traffic. Special roads are ways built by agencies, business entities, individuals, or community groups for their own interests. Parts of the road include road benefit space, road space, and road control space:

- Space benefits include road bodies, roadside channels and safety thresholds. 
- Road space includes space for road benefits and a particular ground line out of the road benefit space.

- Road supervision space is a certain room out of the existing road space under the supervision of the road organizer.

\subsection{Concrete road}

Concrete road is a pavement that uses cement as a binding material so that it has relatively high stiffness when compared to flexible pavement, that it is more commonly referred to as rigid pavement (Anas Ali, 2000). Concrete pavement, which is rigid and having high elastic modulus will distribute load towards a fairly wide area of land. Therefore, the biggest part of the pavement structure capacity is obtained from the concrete plate itself. Concrete road is a structure consisting of cement concrete plate connected with or without reinforcement located in the upper layer of lower foundation or sub-grade, without or with asphalt surface layers. Structure and types of cement concrete pavement are classified into four different kinds: (Pd T-14-2003 department of settlement and regional infrastructure 2003)

1. Connected cement concrete pavement without reinforcement

2. Connected cement concrete pavement with reinforcement

3. Intact cement concrete pavement with reinforcement

4. Pre-strained cement concrete pavement

\subsection{Kinds of Concrete Road Damages}

According to the standard book of the Directorate of Highways NO. 10 / T / BNKT / 1991, rigid pavement damage can be classified as follows:

1. Damage caused by surface characteristics.

a. Local crack is a crack, which does not reach the lower part of the slab.

b. Faulting is a damage caused by irregular arrangement around or along the lower layer of the ground and faulting of connection

c. Deformation is unevenness in the longitudinal direction of the road.

d. Abrasion is a damage in the surface of the concrete pavement where it can be classified into:

2. Release of grain is a condition where the aggregate layer of the road surface is separated from the concrete mixture and what makes road become rough. 
1. Polishing is a condition where the mixture of concrete and aggregate on the surface becomes very slippery due to friction.

2. Wear is an erosion of the road surface caused by the friction of the vehicle wheels.

3. Structure damage

a. Cracks in this case is referred to cracks reaching the lower part of the slab.

b. Buckling is divided into:

6. Blowing up is a condition where concrete slab becomes bent and buckling due to the tension of the inside of the concrete.

7. Destruction is a condition where concrete slab is experiencing such disintegration due to the pressure tension in the concrete. In general, this case happens around the connection.

\subsection{Road Users}

Another factor, which causes damage to roads, other than planning, implementation, maintenance, and nature is road users. The behavior factor of road users, whether it is intentionally or unintentionally, can cause road damage, including in the form of accidents, and vehicle load that exceeds the predetermined tonnage.

\subsection{AHP Method (Analytical Hierarchy Process)}

Analytical Hierarchy Process (AHP) is a technique for solving problems in term of decision-making done by using various criteria. It was first introduced by Thomas L. Saaty (1971-1975). AHP is not only used to determine the priority of choices with many criteria, but it also offers resolution of decision making by involving all sources of complexity. AHP simply relies on intuition as the main input. Decision-making is made by sufficiently getting information and understanding the encountered issues related to decision-making. There are several principles need for understanding relevant to AHP, such as decomposition, comparative judgment, synthesis of priority and logical consistency.

\subsection{Frame Work of the Resarch}

Road segments of Pemalang - Tegal are very busy, in addition, damages such as holes and cracks/ surface defects are everywhere, that immediate action to handle this issues is required. Purpose of this study is to determine factors that cause damage to the concrete road in terms of implementation. Further, it is also an attempt to find out the most dominant causes of damage and to get to know how to handle it. 
Results of this study will be revealed after describing the data done by using SPSS and by implementing the methods of handling road damage using the AHP (Analytical Hierarchy Process) method.

\section{Research Methods}

\subsection{Stage of Research}

Belows are the stages of the research:

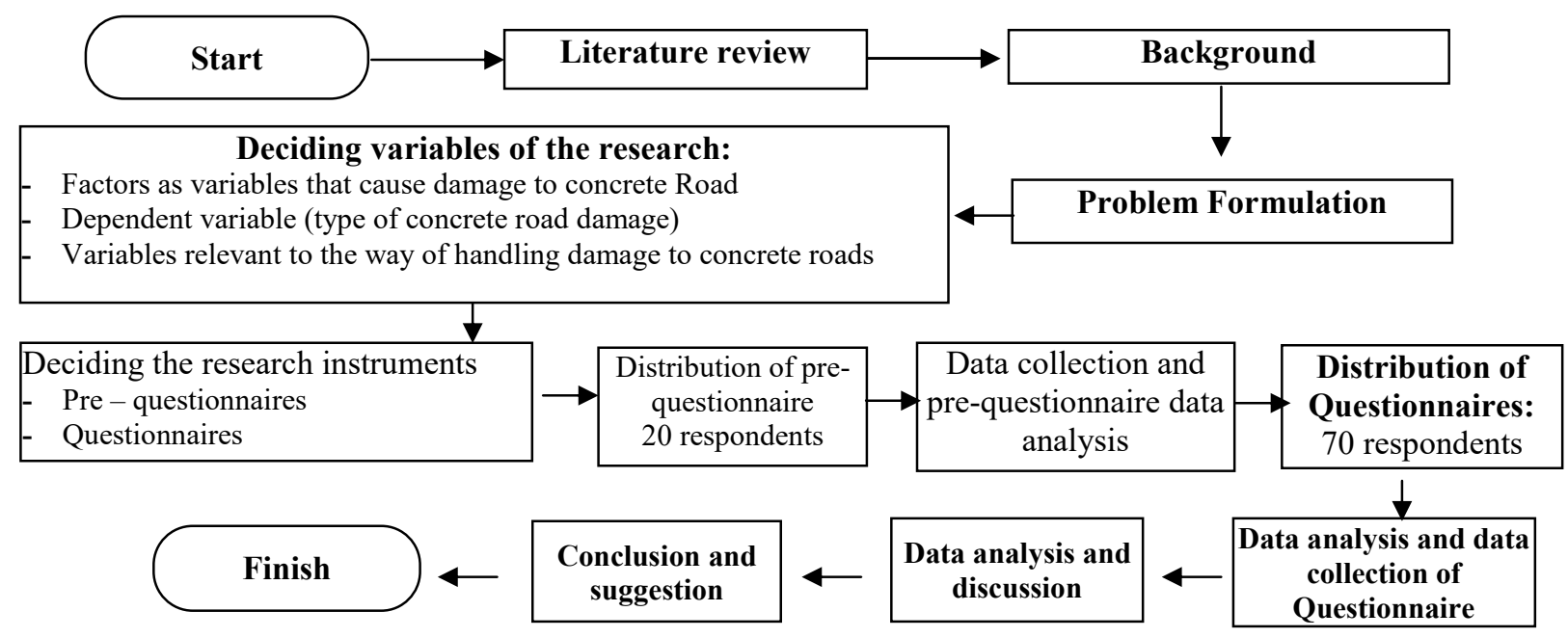

\subsection{Framework of Resarch Content}

This research was conducted in the city of Tegal and the regency of Pemalang through analyzing the damage to the concrete road in the form of a case study. The case study itself is research on a research subject relating to a specific or typical phase of the overall personality (Hasan, 2002). Judging from its purpose, this study belongs a correlation study conducted by looking for the most influential factors or factors that cause damage to concrete roads. In addition, it was also a way to find out the dominant damaging factors to the concrete road segments in the line of Pemalang - Tegal, and also a way to get to know how to deal with the damages to the concrete roads.

\subsection{Population and Sample}

Population is a group of people, events or anything that has certain characteristics (Indriantoro and Supomo, 2016). Population in this research included executors, consultants, academics and related institutions, with the criteria of having a minimum education qualification of senior high school or equivalent; having been in the field of road construction 
for at least 3 years, and having been directly and indirectly involved in handling roads of Pemalang - Tegal. In total there were approximately 70 people taking a part in this research, consisting of executors, consultants, academics, and related agencies.

Census is a kind of sampling method used in this research all members of the population were used as samples

\subsection{Respondent of the Research}

In order to get representative respondents in accordance with the aim of the research, determination of respondents was made by mentioning such as the relevant institutions (the office of Public work), consultants (with the post of Site Engineer, Chief Inspector, Quality Control, Engineering Laboratory staff, Inspector and Surveyor), contractor (with the post of General superintendent, quality laboratory staff, executor and surveyor) and academician (regional government and lecturers), by which all involved had to meet the predetermined criteria; having the minimum education qualification of Senior High School, and outside of the academicians working in the field of road construction for at least 3 years.

Determination of the direct sample size was made by taking the existing sample. For the number of sample was less than 100, the samples were following the existing samples.

In this research, the number of sample set was 20 respondents for pre - questionnaires and 70 respondents were for questionnaires.

\subsection{Method of Data Collection}

Primary data is a source of data obtained directly from the original source, and specifically collected by researchers to answer the research questions. These data are adaptable to what the researchers want. Supposed that there are data which are not relevant to the research objectives, they can be eliminated or at least reduced. The followings are two methods applicable to collect primary data (Indriantoro and Supomo 2016):

1. Method of Survey

2. Method of Observation

Referring to the framework of this research, method of survey was used.

Socondary data used by the researcher were indirectly obtained from intermediaries such as evidences, notes, or historical reports arranged in the published and unpublished archieves. 


\subsection{Determination of Variable and Method of Measurement}

\subsubsection{Determination of Variabel}

There were two stages of determining the research variables:

\section{Stage I (Pre-Questionnaires)}

This was an exploratory stage trying to explore possible factors affecting the concrete road damages in the frame of implementation in the road segments of Pemalang - Tegal. Data collection in this stage was made by literature review and through guided interview with pre questionnaire as the guideline where it was made to 20 respondents taken from the office of public work (head of sub-department, head of section, and head of unit), consultants (with the post of site engineer, and chief of inspector), contractors (with the post of General Superintendent, and executor) and academicians (Lecturer and local government), competent in the research. Result data from the first stage research instrument (pre - questionnaire) were used as the basis in organizing second stage research instrument (Questionnaire).

\section{Stage II (Questionnaires)}

Research instrument in this stage was organized based on the research result in the previous stages (pre-questionnaire). In the stage of questionnaire, there were three variables about to being measured:

a. The variables of damage factors

b. The variables of dominant damages

c. The variables of damage handlings

Data collection in the stage of questionnaire was made through literature review and guided interview with the questionnaire guidline as the reference made to 70 respondents at the office of public work, consultant, contractor and academician competent in the research.

\subsection{Method of Data Analysis}

The literature used as a reference in the data analysis of this research was the Exercise Book of Parametric Statistics SPSS (Santoso, 2000). SPSS 19 was used as an analytical tool to determine the factors that cause damage to the road and the types of the most dominant road damages, while Analitycal Hierarchy Process (AHP) method was used as an analytical tool to determine the priority of how to handle road damage. 


\section{Results and Discussion}

\subsection{Result of the Research}

From the results of the research on the analysis of rigid pavement road damage in the road segments of Pemalang - Tegal, the following results were obtained:

Validity and reliability tests of the questionnaires were made to 70 respondents. In the research, the questioinnaire reliability was measured once (one-shot) by the help of SPSS program. Result in the validity and reliability tests of the questionnaire in short are as follows:

Table. 1 Validity and reliability test result of questionnaire related to the causes of road damage

\begin{tabular}{|l|c|c|c|}
\hline \multicolumn{1}{|c|}{ Variabel } & R result & R table & Remark \\
\hline Factors that affect damage to the concrete roads & & & \\
Implementation & 0,711 & 0,468 & Valid \\
1. Poor construction materials & 0,543 & 0,468 & Valid \\
2. Poor material processing system & 0,672 & 0,468 & Valid \\
3. Poor compaction process & 0,474 & 0,468 & Valid \\
4. Poor supervision towards implementation & 0,488 & 0,468 & Valid \\
5. Concrete slump above $10 \mathrm{~cm}$ & 0,537 & 0,468 & Valid \\
6. Poor concrete Curing & 0,579 & 0,468 & Valid \\
7. Open time for traffic is too fast $<28$ days & 0,683 & 0,468 & Valid \\
8. Late Concrete cutting & & 0,677 & Reliabel \\
\hline Cause Alpha of Road damage & & & \\
\hline
\end{tabular}

Source: Processed Primary Data

\subsubsection{Descriptive Analysis}

Descriptive analysis is a kind of analysis describing frequency distribution of each research variable, this description was made by referring to the pre-determined criteria, where these criteria have 5 components, criteria for factors causing the road damage were made into scales, criterion 1 (very low) for the aveage score of answer $1.00-1.50$, which means it is not influence; criterion 2 (low) for the average score of answer $1.51-2.50$, which means it is not too influential; criterion 3 (average) for the average score of answer $2.51-3.50$, which means it is influential; criterion 4 (high) for the average score of answer $3.51-4.50$, which means it is very influential; and criteria 5 (very high) for the average score of answer $4.51-5.00$, which means it is very much influential. Independent variable where it was suspected to be the causing factors of the road damage was implementation, while dependent variable in this case was revealed to be the kinds of road damages. 
Table 2 The criteria average of factors causing road damage from the aspect of Pemalang - Tegal road implementation in the year of 2017

\begin{tabular}{|c|c|}
\hline Road damage causing factors & The Average of Criteria \\
\hline 1. Poor construction materials & 3,79 \\
\hline 2. Poor material processing system & 3,89 \\
\hline 3. Poor compaction process & 3,60 \\
\hline 4. low supervision towards implementation & 3,20 \\
\hline 5. Concrete Slump above $10 \mathrm{~cm}$ & 3,31 \\
\hline 6. Poor concrete Curing & 3,80 \\
\hline 7. Open time for traffic was to fast $<28$ days & 3,41 \\
\hline 8. Late concrete cutting & 3,46 \\
\hline
\end{tabular}

Table 2 shows respondents' answer score upon the questions distributed relevant to the cause of road damage in the aspect of implementation. Of the eight factors, question number 2 showed the highest response, which is poor material processing systems with the score of 3.80. The smallest cause of damage is number 4, which is poor supervision towards the implementation with the score of 3.20 .

Score frequency distribution of kinds of road damages in Pemalang - Tegal in 2017. As shown in the table 3.

Table 3. score frequency distribution of kinds of road damages in Pemalang - Tegal in 2017.

\begin{tabular}{lcc}
\hline \multicolumn{1}{c}{ Criteria } & Frequency $(\mathrm{n})$ & Percentage $(\%)$ \\
\hline 1 (Very low) & 0 & 0 \\
2 (Low) & 0 & 0 \\
3 (Average) & 63 & 90,00 \\
4 (High) & 6 & 8,57 \\
5 (Very High) & 1 & 1,43 \\
\hline Total & 70 & 100 \\
\hline
\end{tabular}

Source: Processed Primary Data

Table 3 shows that the majority of respondents' answers to questions on the type/ form of damage that occurred was mostly in the average criteria (average answer score was 2.513.50) which reached $63(90.00 \%)$, and there were no criteria of very low and low. The criteria average for each type of variable/ form of damage in the road of Pemalang - Tegal in 2017 is shown in table 4. 
Table. 4. The criteria averages for types/ form of damage in the road of Pemalang - Tegal in 2017

\begin{tabular}{lc}
\hline \multicolumn{1}{c}{ Kinds/ forms of road damages } & Average of Criteria \\
\hline 1. Local Cracks & 3,59 \\
2. Irregular fracture & 3,23 \\
3. Lengthwise unevenness deformation & 2,94 \\
4. Abrasion, granule release, wear & 3,89 \\
5. Connection damage, at the end of the connection & 3,67 \\
6. Hollow & 2,84 \\
7. Expanding cracks, reaching the bottom of the slab & 3,36 \\
8. Curved & 2,44 \\
9. Destroyed & 2,74 \\
\hline
\end{tabular}

Source: Processed Primary Data

Table 4. shows that abrasion is the kind of issue that gives the biggest impact to the road damages. It has the average value of 3.89 , while the lowest one is number 8 "Curved" where it has the average value of 2.44 .

\subsubsection{Calculation of AHP Analysis}

This calculation process was related to pairwise comparisons. Decision-making began with determining the overall decision hierarchies. The following is the calculation adopting the use of AHP method on the questionnaire number one with the criteria of Abrasion damage, granular release, and wear:

- Determining pairwise comparison matrices

- Determining factor evaluation

- Calculating consistency ratios

\subsubsection{Criteria Assessment}

As only one criterion in this research, it was used as an assessment to determine the best damage management strategy. Therefore, we could immediately get the first ranking result; handling with an overlay.

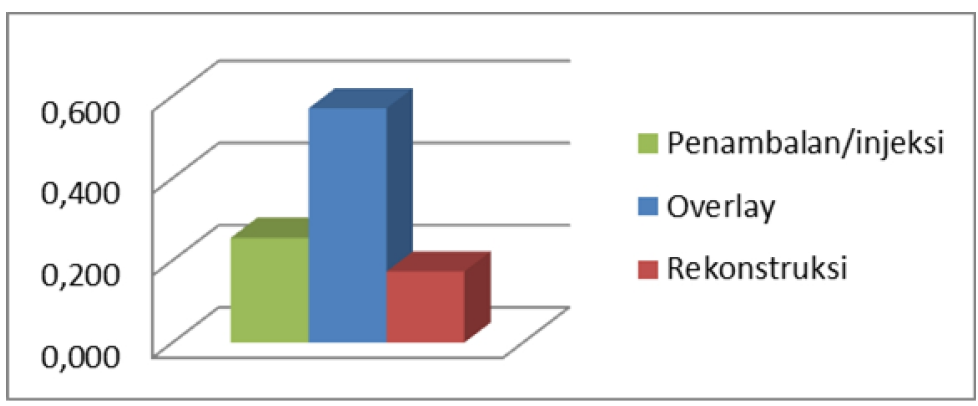

Figure1 Rank Histogram of Abrasion Handling 
Based on the results of the excel analysis, it is reported that for the abrasion criteria, the release of granules, the first handling alternative wear is Overlay with a value of 0.571 , then an injection handling alternative/ fillings with the value of 0.255 , and the last alternative is reconstruction with a value of 0.173 .

\subsection{Discussion}

\subsubsection{The causes of road damage reviewed from the aspect of implementation}

Poor material processing systems with a score of 3.89 is respondents' answers to questions relevant to the causes of road damage reviewed from the aspect of the highest implementation. Therefore, in the implementation process, the operational standard of a good material processing system needs to be available to generate high quality concrete. Another thing to consider is the sufficiency of finance for the project implementation, and so the implementation quality becomes reliable in the process and the result of which will be as expected

\subsubsection{The causes of the most dominant road damage}

Respondents' responses upon the questions relevant to the causes of the most dominant road damages are abrasion, granule release, and wear with the score of 3.89. In this case, the way to handle road damages due to abrasion, granule release and wear by using AHP method is needed.

\subsubsection{Priority in handling road damage}

Abrasion, granule release, and wear were the most dominant damages happening in the road segments of Pemalang - Tegal. From the respondents' response, data were analyzed by using AHP method. Result of which suggests that the most efficient way of handling the issue is by overlaying the broken road surface.

\section{Conclusion}

Based on the result in the research on the analysis of road damage in Pemalang - Tegal in the year of 2017, it can be concluded that:

1. Poor material processing system becomes one of the factors, which causes concrete road damage in the segments of Pemalang - Tegal reviewed from the aspect of implementation. When the concrete material spread out in the project site is 
homogeneous, such damage can be minimized, homogeneous in the sense is when it is applied in the space the condition of the concrete should remain the same as when it comes out from the batcing plant. This is because the application in the field is still using manual devices, rather than using concrete paver.

2. Abrasion, granule release, and wear were the most dominant factors which caused the concrete road damage in the segments of Pemalang - Tegal. It happened due to the fact that the concrete spreading did not use concrete paver, as a result, the finishing of work was not evenly distributed and caused granule release in several location.

3. The best priority of handling is by overlaying in the damaged location. Overlyaing has several benefits among which are faster work, more efficient and cheaper compared to using the method of reconstruction or injection, as it takes more time, funding and energy compared to overlaying.

\section{Reference}

Anas Ali Moh. (2000). Modul Kursus Singkat Perkerasan Beton Semen, Himpunan

Pengembangan Jalan Indonesia, Provinsi Riau.

Departemen Permukiman dan Prasarana Wilayah, (2003). Perencanaan Perkerasan Jalan Beton Semen, Jakarta

Dipohusodo, Istimawan. (1996). Management Proyek dan konstruksi, Kanisius, Yogyakarta.

DPU Bina Marga. (1991). Tata cara Pemeliharaan Perkerasan Kaku (Rigid Pavement), Dirjen Bina Marga, Direktorat Pembinaan Jalan Kota, Jakarta

Effendi, S dan Tukiran. (2012). Metode Penelitian Survei, LP3ES, Jakarta

Hardiyatmo Hary Christady. (2007). Pemeliharaan Jalan Raya, Gadjah Mada University Press, Yogyakarta

Hasan, M. Iqbal. (2002). Pokok-pokok Materi Metodologi Penelitian dan Aplikasinya, Ghalia Indonesia, Jakarta.

Indriantoro, N dan Supomo, B, (2016). Metodologi Penelitian Bisnis, BPFE-Yogyakarta.

Kristiawan, SA. (2011). Kompatibilitas Susut antara Material Perbaikan dan Beton, Jurnal Teknik Sipil

Saaty, T.L.(1988). Multicriteria Decision Making : The Analytic Hierarchy Process. University of Pittsburgh, RWS Publication, Pittsburgh 
Salim, H.A. Abbas. (1993). Manajemen Transportasi, PT Raja Grafindo Persada, Jakarta

Santoso, Singgih. (2000). Buku Latihan SPSS Statistik Paranietrik, PT. Elex Media Komputindo, Jakarta.

Singarimbun, M., dan Effendi, S. (1999). Metode Penelitian Survey, LP3ES, Jakarta

Soeharto, Imam. (1997). Managemen Proyek, Erlangga, Jakarta

Sugiyono (2015). Metode Penelitian Kuantitatif Kualitatif dan R\&D, Afabeta, CV, Bandung

Sukirman, Silvia. (1995). Perkerasan Lentur Jalan Raya, Nova, Bandung

Undang-Undang Republik Indonesia No 38 Tahun 2004 tentang Jalan

Usman, H., Akbar, R.P.S. (1995). Pengantar Statistika, Bumi Aksara, Jakarta

Walpole, Ronald E., dan Raymond H. Myers, (1986). Ilmu Peluang dan Statistika untuk Insinyur dan Ilmuwan, Penerbit ITB, Bandung

Warpani, S. (1990). Merencanakan Sistem Perangkutan, Penerbit ITB, Bandung 